\title{
Leadership Nature of Commanders in Royal Thai Air Force
}

\author{
Prasit Sangomek $^{1}$, Somchai Ratanakomut ${ }^{1}$, Supachok Wiriyacosol ${ }^{1} \&$ Wiriya Meesiri ${ }^{2}$ \\ ${ }^{1}$ School of Management, Shinawatra University, BBD Building 197 Viphavadi-Rangsit Road, Samsen Nai, Phayathai, \\ Bangkok 10400, Thailand \\ ${ }^{2}$ Directorate of Education and Trainning, Royal Thai Air Force, Donmaung, Bangkok 10210 Thailand \\ Correspondence: Prasit Sangomek, School of Management, Shinawatra University, BBD Building 197 \\ Viphavadi-Rangsit Road, Samsen Nai, Phayathai, Bangkok 10400, Thailand. E-mail: psankk@gmail.com
}

Received: June 12, 2013

doi:10.5430/bmr.v2n3p113
Accepted: July 5, 2013

Online Published: September 2, 2013

URL: http://dx.doi.org/10.5430/bmr.v2n3p113

\begin{abstract}
The Royal Thai Airforce is applying Leadership theories and principles in modernizing the organization. This paper explores the nature of Leadership in The Royal Thai Airforce to gain some fundamental information which may be useful in a long term planning. Relevant theories of Leadership are reviewed. Three major types of Leadership styles are considered: transformation, transaction, and Laissez-Faire. 30 commanders with ranks equal or higher than squadron leader with experience in RTAF at least 10 years were selected for a questionnaire survey. The majority Leadership characters found is transformation Leadership characters $(X=3.99$ out of 5$)$ follows by Laissez-Faire (3.67) and transaction (3.44). All the Transformational Leadership characters possess high score: Idealized Behavior (3.94), Inspirational Motivation (3.93), Intellectual Stimulation (3.89), and Individual Consideration (4.21) show high scores while active management by exception gains only moderate score (3.35) and so are passive management by exception ( 2.99). Laissez-Faire Leadership shows also a high score (3.67). At this stage of investigation the reasons for the existing distribution of Leadership characters in RTAF and how the planned distribution should be are unknowns and need further investigation.
\end{abstract}

Keywords: Leadership, Transformation leadership, Transactional leadership, Laissez-faire, Military, Air force, Leader, Commander

\section{Introduction}

Both Leadership and management are needed to achieve organization quality. When practicing together, they would provide the foundation of inspiration, capability, and effectiveness. The processes of Leadership begin with the leaders communicate to the followers about a clear mission, vision, and values of organization's ultimate achievement. The leaders then encourage others to change their culture willingly and moving forward along the expected pattern of behavior. The In this case, The Royal Thai Air Force (RTAF) is undergoing personnel development programs following the Public Sector Management Award (PMQA) guidelines. RTAF expects leaders to succeed implement to the right patterns' behavior following the guidelines (Sangomek \& Ratanakomut, 2010). This paper reports the study of the Leadership characters in RTAF, The quantitative methodology is used to investigate the Leadership's nature of senior officers in RTAF. This pilot investigation focuses on a 30 participants in RTAF selected from those who are willing to answer the questionnaire The results found from this study will be used for further investigation in a continual attempt to develop Leadership ability of RTAF personnel following the PMQA guidelines.

\section{Literature Review}

Since the studies of Leadership emphasized on Leadership traits and defined physical and personal characteristics. (e.g. Barnard, 1938; Ghiselli, 1971; Stogdill, 1948) Evolving Leadership has shifted to Leadership styles that focused on Leadership development to respond to the task requirement, and situational constraints. (e.g. Blake \& Mouton, 1964; Likert, 1961; McGregor, 1960) The contingency theories have been described different patterns of traits for different situations. (e.g. Fiedler, 1967; Vroom \& Yetton, 1973) However, the follows' behaviors have been changed to more emphasis on being leaders. As this reason, the engagements of leaders to followers developed to explore the suitable process to influence the followers achieve shared objectives. (Bethel, 1990; Rosenbach \& Taylor, 1993; Bohn \& Grafton, 2002; Heilbrun, 1994) 
The Leadership theories have been changed to the interactive process between leaders and followers. Transformational leader is defined the leaders must motivate followers to action by influencing the followers to trust, admire and respect to their leaders. Transactional leader's definition is leader who reinforces followers to succeed their goal immediately or delayed in term of rewards or resources. Moreover, Laissez- Faire is leader who avoids the responsibilities, fails to support their followers and resists their important issues. (Burns, 1978; Bass, 1985; Bass \& Avolio, 1990; Avolio et al. 1991; Pounder, 2001; Kim \& Shim, 2003) Differences between Bass' and Burns' Leadership ideas are shown in the following table.

Table 1. Comparison of Bass and Burns' Leadership Concepts

\begin{tabular}{|c|c|}
\hline Burns & Bass \\
\hline Transactional Leadership & Transactional Leadership \\
\hline $\begin{array}{l}\text { Approaches followers with an eye to exchanging } \\
\text { one thing for another. }\end{array}$ & $\begin{array}{l}\text { Pursues a cost benefit, economic exchange to met } \\
\text { subordinates current material and psychic needs in } \\
\text { return for "contracted" services rendered by the } \\
\text { subordinate." }\end{array}$ \\
\hline \multirow{3}{*}{$\begin{array}{l}\text { Transformational Leadership } \\
\text { "recognizes and exploits an existing need or } \\
\text { demand of a potential follower...(and) looks for } \\
\text { potential motives in followers, seeks to satisfy } \\
\text { higher needs, and engages the full person of the } \\
\text { follower" (Burns, 1978). }\end{array}$} & Transformational Leadership \\
\hline & $\begin{array}{l}\text { The leader who recognizes the Transactional } \\
\text { needs in potential followers "but tends to go } \\
\text { further, seeking to arouse and satisfy higher } \\
\text { needs, to engage the full person of the follower ... } \\
\text { to a higher level of need according to Maslow's } \\
\text { hierarchy of needs" (Bass, 1985). }\end{array}$ \\
\hline & $\begin{array}{l}\text { Also use their authority and power to radically } \\
\text { reshape through coercive means the social and } \\
\text { physical environment, thus destroying the old way } \\
\text { of life and making way for a new one. }\end{array}$ \\
\hline
\end{tabular}

\section{Source: Leadership Models: From Weber to Burns to Bass, United Nation (Public Administration Network).}

Transformational Leadership and Transactional Leadership are described Leadership behavior on seven dimensions: four Transformational ones, two Transactional ones and Laissez-Faire, or the absence of true Leadership. The seven dimensions were: (1) Laissez-Faire; (2) Management-by-exception; (3) Contingent reward; (4) Individualized consideration; (5) Intellectual stimulation; (6) Inspirational motivation; and (7) Idealized influence, of which item (2) to (3) belong to Transactional Leadership and item (4) to (7) belong to Transformational Leadership.

The Laissez-Faire leader allows followers to do as they please and abdicates responsibility towards them. He or she refrains from intervening, avoids taking a stand on issues, and is often absent, disorganized and indifferent. Laissez-Faire Leadership really refers to an absence of Leadership, and typical follower reactions include conflict over responsibilities and attempts to usurp the role of leader.

Transactional Leadership involves role clarification, the initiation of structure, attempts to meet the social needs of subordinates, and the distribution of rewards and punishment according to performance. It relies on management-by-exception (MBE) and/or contingent reward where only some exceptionally important management issues are considered while the rest are ignored. Leaders who exclusively practice MBE take action only when there is evidence of something not going according to plan. There are two types of MBE : active and passive. Active MBE describes a leader who actively searches for variances from expectations, and takes action when irregularities are identified. The passive form of MBE describes a tendency to intervene, often reluctantly, only when specific problems become apparent, or are drawn to the attention of the leaders. Leaders who follow MBE tend to avoid initiating change and risk taking, preferring instead to maintain the status quo. Contingent reward is an exchange process where the leaders and followers agree roles and responsibilities for reaching designated goals. Leaders provide rewards, for example in the form of praise, pay increases, bonuses and promotion when followers perform adequately. Contingent reward Leadership can be quite effective, for it is associated with both improved performance and the satisfaction of followers (e.g. Keller, 1995).

Transformational Leadership, when successfully applied, arouses a heightened awareness of the key issues for the organization. It develops followers concern with achievement, growth and development, stimulates interest among colleagues and followers to view their work from new perspectives. Transformational Leadership generates awareness of the mission or vision of the organization, develops colleagues and followers to higher levels of ability and potential, and motivates others to transcend self-interest so as to benefit the organization as a whole (Bass and Avolio, 1994). 
According to the above review, the researchers found that Transactional Leadership and Transformational Leadership were appropriate for organizations that focus on change and innovation which was the essential characteristic of the balanced scorecard (Senge, 1990). With this reason, researcher adopted Bass and Avoli (1990)'s Leadership theory in this study. Thus, the dimensions of Leadership considered were those of Transformational, Transactional, and Laissez-Faire. Within each dimension there were some selected Leadership characters to be measured as follows :

\section{Transformational Leadership:}

1. Individualized Consideration.

2. Intellectual Stimulation.

3. Inspirational Motivation.

4. Idealized Influence.

Transactional Leadership:

5. Management-by-exception.

6. Contingent Reward.

\section{Laissez-Faire Leadership}

7. Laissez-Faire.

\section{Method}

This study was conducted in RTAF, Thailand. The participants of this study were from six directorates within RTAF: Royal Thai Air Forces Headquarters, Commander Force, Flight Operation Force, Logistic Force, Education and Training Force, and Special Force. The data were collected from officers who are higher ranks than Squadron Leader (O4) who had working experience more than ten years and had sufficient knowledge about Leadership style practiced in the organizations.

Flexible survey questions which related to three issues: Transformational Leadership, Transactional Leadership and Laissez-Faire Leadership were designed and used in a questionnaire survey.

\subsection{Limitations}

The study is a pilot attempt that may indicate the existing condition in RTAF. Only some fundamental information are shown and discussed. It is necessary that some future work is necessary for deeper and more detail investigation.

\subsection{Participants}

Non-probability sampling procedure was adapted by the judgment sample which the researchers actively select the most productive samples to answer the research questionnaires. The participants were selected from 30 senior officers: those with higher ranks than Squadron Leader $(\mathrm{O} 4)$ with experience more than 10 years in the air force.

Table 2. The Commissioned Rank Structure within the Royal Thai Air Force, Thailand

\begin{tabular}{ccc}
\hline Full Rank & Abbreviation Rank & Rank Level \\
\hline Air Chief Marshal & Air Chf. Mshl. & O9 \\
Air Marshal & Air Mshl. & O8 \\
Air Vice-Marshal & AVM & O7 \\
Group Captain & Gp.Capt. & O6 \\
Wing Commander & Wg.Cdr. & O5 \\
Squadron Leader & Sqn.Ldr. & O4 \\
Flight Lieutenant & Flt.Lt & O3 \\
Flying Officer & Fg.Off. & O2 \\
Pilot Officer & Plt.Off. & O1 \\
\hline
\end{tabular}

\subsection{Procedure}

The sampling design for the quantitative study started with an identification of samplings which are the senior officers in RTAF who are in active service. Questionnaires were sent to the sampled persons. The official letters and guidelines of required information were enclosed together in order to make understanding about the survey objectives and information which will be collected and recorded by the researcher. 


\subsection{Instrumentation}

In this study, Leadership character indicators are defined for Transformational, Transactional and Laissez-Faire Leadership style. Transformational Leadership include: (1) Individualized Consideration, (2) Intellectual Stimulation, (3) Inspirational Motivation, and (4) Idealized Influence. Transactional Leadership includes: (2) Management-by-exception, (3) Contingent Reward. Laissez-Faire Leadership include only one indicator: (1) Laissez-Faire. A five level Likert scale from 1 to 5 representing very low, low, neutral, high, and very high respectively.

\subsection{Validity Analyses for the Measurement Scales}

In this study, content and face validity was established trough a panel of experts and a field test respectively. The researchers performed the validity check of the instrument by determining its content-related and face-related evidents. Content validity is based on the extent to which a measurement reflects the specific intended domain of content (Carmines \& Zeller, 1991, p.20). For content-related check, a selected panel of experts checked the degree to which the instrument measured an intended content area and was basically judgmental of the representativeness of the items on the instrument (Ary, Jacobs \& Razavieh, 1996). These experts were chosen based on their familiarity with this research framework, knowledge of research-related theories including the operation of the Leadership style. After done with the content-related check, the researchers performed the face-related check. The purpose of face-related check was to see whether the instrument was suitable for the intended audience The target population was asked to comment on the clarity, wording, thoroughness, ease of use, and appropriateness of the instrument (Ary, Jacobs \& Razavieh, 1996).

\section{Result}

The data of this study are analyzed using descriptive and inferential statistics techniques. Fundamental descriptive statistics value including means, standard deviations, frequencies, and percentages will be calculated. The analytical method is adapted to explore the nature of Leadership of commanders in RTAF.

The mean from the result of Leadership Style will be analyzed to the range as follow.

$$
\begin{array}{lll}
3.67-5.00 & = & \text { High } \\
2.34-3.66 & = & \text { Moderate } \\
1.00-2.33 & = & \text { Low }
\end{array}
$$

Table 3. Total quantity and percentage of sample profiles classified by rank ranges

\begin{tabular}{ccc}
\hline Rank Level Range & Quantity & Percentage \\
\hline O7-O9 & 5 & 16.67 \\
O4-O6 & 25 & 83.33 \\
Total & $\mathbf{3 0}$ & $\mathbf{1 0 0}$
\end{tabular}

The rank variable was divided into 2 groups: O7-O9 and O4-O6. Data from the survey indicate that the majorities of respondents were O4-O6 (Squadron Leader to Group Captain), i.e. 25 officers or 83.33 percent.The rank level 07-09 (Air Vice-Marshal to Air Chief Marshal) is 5 officers or 16.67 percent. Details are shown in Table 3.

Table 4. Total quantity and percentage of sample profiles classified by gender

\begin{tabular}{ccc}
\hline Description & Quantity & Percentage \\
\hline Male & 26 & 86.67 \\
Female & 4 & 13.33 \\
Total & $\mathbf{3 0}$ & $\mathbf{1 0 0}$ \\
\hline
\end{tabular}

The gender variable was divided into 2 groups: male and female. Data from the survey found that 26 officers or 86.67 percent of the questionnaire respondents were male and 13.33 percent or 4 officers were female, as shown in Table 4.

Table 5. Total quantity and percentage of sample profiles classified by education

\begin{tabular}{ccc}
\hline Education & Quantity & Percentage \\
\hline Equal and More Than Bachelor Degree & 17 & 56.67 \\
Less Than Bachelor Degree & 13 & 43.33 \\
Total & $\mathbf{3 0}$ & $\mathbf{1 0 0}$ \\
\hline
\end{tabular}


Regarding to the education backgrounds, the majorities of respondent, in the amount of 17 or 56.67 percent graduated equal and more than the Bachelor degree, followed by 13 or 43.33 percent graduated under the Bachelor degree, as shown in Table 5.

Table 6. Total quantity and percentage of sample profiles classified by working period

\begin{tabular}{ccc}
\hline Working Period & Quantity & Percentage \\
\hline $15-21$ Years & 2 & 6.67 \\
22 -28 Years & 9 & 30.00 \\
More Than 28 Years & 19 & 63.33 \\
Total & $\mathbf{3 0}$ & $\mathbf{1 0 0}$
\end{tabular}

The respondents' working experiences were divided into 3 groups ranging from 15-21 years to more than 28 years. After survey, data found that the majorities of the respondents was for 19 or 63.33 percent has been worked in the air force more than 28 years. Following by the group 22 to 28 years is in the amount of 9 or 30 percent and the group of 15-21 years is in the amount of 2 or 6.67 percent respectively, as shown in Table 6.

The following part represented the result in average (X) and standard deviation (S.D.) of the survey which included Leadership style (Transformational Leadership, Transactional Leadership and Laissez-Faire Leadership) of senior officers in RTAF, Thailand, as shown in Table 7. Moreover, the research calculated the range of average (X) into three parts which were: $1.00-2.33$ was low, $2.34-3.66$ was moderate and $3.67-5.00$ was high.

Table 7. Average and standard deviation of the Leadership Style of respondents work in RTAF, Thailand.

\begin{tabular}{|c|c|c|c|}
\hline $\begin{array}{r}\text { Leadership Style } \\
\end{array}$ & $\mathbf{X}$ & S.D. & Range \\
\hline \multicolumn{4}{|l|}{ 1. Transformational Leadership } \\
\hline 1.1 Idealized Behavior & 3.94 & 0.53 & High \\
\hline 1.2 Inspirational Motivation & 3.93 & 0.52 & High \\
\hline 1.3 Intellectual Stimulation & 3.89 & 0.47 & High \\
\hline 1.4 Individual Consideration & 4.21 & 0.56 & High \\
\hline Total & 3.99 & 0.52 & High \\
\hline \multicolumn{4}{|l|}{ 2. Transactional Leadership } \\
\hline 2.1 Contingent Reward & 3.97 & 0.66 & High \\
\hline 2.2 Management-by-Exception: Active & 3.35 & 0.70 & Moderate \\
\hline 2.3 Management-by-Exception: Passive & 2.99 & 0.65 & Moderate \\
\hline Total & 3.44 & 0.67 & Moderate \\
\hline \multirow[t]{2}{*}{ 3.Laissez-Faire } & 3.67 & 0.58 & High \\
\hline & 3.70 & 0.59 & High \\
\hline
\end{tabular}

Transformational Leadership style of senior officers in RTAF scores a "high" mean score (X=3.99 out of 5) implies that the majority of officers in RTAF show the transformation Leadership characters. Among the transformation Leadership characters, the highest mean range in this part was the category of individual consideration (4.21) i.e. concern for individual needs, abilities, and aspirations of others (3.97). The Laissez-Faire Leadership character also has a "high" mean range $(X=3.67)$. The Transactional Leadership characters score a moderate score of 3.67. It appears that leaders in RTAF are dominated by the majority of transformation Leadership characters which reflect the concern for individual need and aspiration. It is rather surprising for the high score of the Laissez-Faire Leadership which reflects either respect for others' freedom or the "don't bother me" attitude. The Transactional Leadership characters of senior officers in RTAF show a moderate mean score $(X=3.44)$. It appears that the Transactional characters are the minority in RTAF. The reasons why the distribution of Leadership characters is dominated by the transformation and the rather high proportion of Laissez-Faire type are not known and need further investigation. The ideal or desired proportion of different type of Leadership is also unknown.

Among the Transformational Leadership characters, the majorities are those who consider helping others to develop their strengths. $(X=4.21)$. In the second place are those who are able to act in ways that build others' respect for them and consider the moral and ethical consequences of decisions. $(\mathrm{X}=3.94)$. In the third place are leaders who considers enthusiastically about what needs to be accomplished ensuring that goals will be achieved $(X=3.93)$. The fourth place are leaders who seek differing perspectives when solving problems and suggest new ways of looking at how to complete assignments $(\mathrm{X}=3.89)$. 
Among the Transactional leaders: The majority are leaders who discuss in specific terms that are responsible for achieving performance targets and expect to receive when performance goals are achieved $(X=3.97)$. In the second place are leaders who concentrate full attention on dealing with mistakes, complaints, and failures $(\mathrm{X}=3.35)$, In the third place are leaders will wait for things to go wrong before taking action and believer in if it isn't broke, don't fix it $(\mathrm{X}=2.99)$.

The existence of Laissez-Faire Leadership in a large proportion (3.67) is rather unexpected and no explanation is available and needs further study.

\section{Discussion}

In this study the nature of Leadership in RTAF were investigated. The samples of 30 officers were studied based on three types of Leadership styles: transformation, transaction, and Laissez-Faire. The majority Leadership characters found was transformation Leadership characters ( $X=3.99$ out of 5) followed by Laissez-Faire (3.67) and transaction (3.44)

All the Transformational Leadership characters possess high score: Idealized Behavior (3.94), Inspirational Motivation (3.93), Intellectual Stimulation (3.89), and Individual Consideration (4.21) show high scores while active MBE gains only moderate score (3.35) and so were passive MBE (2.99). Laissez-Faire Leadership showed a surprising high score (3.67). At this stage of investigation the reasons for the existing distribution of Leadership characters in RTAF and how ideally the distribution should be are unknowns and need further study.

\section{Conclusion}

This reason has been supported from many researches finding that there are many academic studies of Leadership, some of which have been conducted in military settings. One of the early studies of Leadership in the military involved all officers of the Royal Thai Air Force who were arranged to be Leadership. Similarly, the relationship between leaders and followers relies on higher levels of motivation and morality.

Within Transformational Leadership construct, the individual consideration was the highest level. It shows that commanders in RTAF display strength in treating each follower individually, coaching and advising them and recognizing followers' achievement. Therefore, these commanders try to find opportunities to work with their followers. Nevertheless, the overall Transformational Leadership level of RTAF officers was high, that have shown that the commanders focus on a relationship to high level of motivation and morality. Moreover, these officers need to transform followers by transforming followers' values and trusts. As the reason that the RTAF officers are trained and educated the Leadership in every course, they learn to enhance communication, team building and Leadership development to be commanders.

However, the result of the high average score in the Transactional Leadership (Contingent Reward) has shown that some officers in RTAF believe the Transactional contingent reinforcement as the core component of effective Leadership behavior in organizations. Exhibiting Transactional Leadership meant that followers agreed with, accepted, or complied with the leader in exchange for praise, rewards, and resources or the avoidance of disciplinary action. Rewards and recognition were provided contingent on followers successfully carrying out their roles and assignments.

\section{Limitation}

It is clear that this study was somewhat biased in terms of obtaining access to the targeted samples for interviews. All of the targeted samples work in Bangkok, Thailand. The outside area took a quite long time for contacting with the targeted samples and follow up the permission of interviews. However, the data analysis has been highly advised from consultants. Another limitation was relevant to the scope of the study. This study has explored the leadership in Royal Thai Air Force only and focused on only three leadership style. It is assumed that these leadership styles are concerned in most of institute in RTAF and relied on Public Sector Management Awards (PMQA). As a result, the effective leader practices and strategies might be excluded.

\section{Recommendation}

Further researches are suggested to investigate leadership and PMQA in-depth. The study should be used both the qualitative method to conduct a quantitative study in order to get more accurate facts regarding the relationship of leadership and PMQA practice in RTAF. Moreover, Directorate of Training and Education (DTE) is the top producer of officers for Thai Air Force. This study may provide some useful information for DTE. It seems that further research, planning, and personnel development is still needed in order to achieve the Royal Thai Air Force's vision to be "One of the Best Air Force in ASEAN". 


\section{Acknowledgements}

I wish to acknowledge and express thanks to my consultants for his assistance in helping in English, guiding and steering this effort in the appropriate direction as well as for his efforts in leading the research forum from which this research topic was derived.

\section{References}

Ary, D., Jacobs, L. C., \& Razavieh, A. (1996). Introduction to Research in Education (5 ${ }^{\text {th }}$ ed.), Fortt worth: Harcourt Brace Collegde Publishers.

Avolio, B.J., \& Bass, B.M. (1991). The full range of Leadership development. Binghamton, NY: Bass, Avolio \& Associates.

Bass, B.M. (1985). Leadership and performance beyond expectations, The Free Press. New York, NY.

Bass, B.M. \& Avolio, B.J. (1990a). The implications of Transformational and Transactional Leadership for individual, team, and organizational development, in Richard, W.W. and William, A.P. (Eds), Research in Organizational Change and Development, Vol. 4, JAI Press, Greenwich, CT.

Bass, B.M. \& Avolio, B.J. (1994). Transformational Leadership and organizational culture, International Journal of Public Administration. http://dx.doi.org/10.1080/01900699408524907

Bennis, W. \& Nanus, B. (2003). Leaders: The Strategies for Taking Charge, New York: HarperCollins.

Bernard, C.I. (1938). The Functions of the Executive; Harvard University Press: Cambridge, MA, Thirtieth Anniversary Edition.

Bethel, S.M. (1990). Making the Difference: Twelve Qualities That Make You a Leader, Berkley Publishing Group, New York, NY.

Blake, R.R., \& Mouton, J.S. (1964). The management grid. Houston TX: Gulf.

Bohn, J.G. \& Grafton, D. (2002), "The relationship of perceived Leadership behaviors to organizational efficiency", Journal of Leadership \& Organizational Studies, Vol. 9 No. 2. http://dx.doi.org/10.1177/107179190200900206

Burns, J.M. (1978). Leadership, Harper \& Row, New York, NY.

Carmines, E.G., \& Zeller, R.A. (1991). Reliability and validity assessment, Thousand Oaks, CA: Sage.

Fiedler, F.E. (1967). The theory of Leadership effectiveness. New York. McGraw - Hill.

Gayvert, D.R. (1999). Leadership and doctrinal reform. Military Review.

Ghiselli, E.E. (1971). Explorations in Managerial Talent. Pacific Palisades, CA: Goodyear.

Heilbrun, I. (1994). “Can leaders be studied?”, The Wilson Quarterly, Vol. 18 No. 2.

Keller, R. T. (1995). Transformational’ Leaders Make a Difference. Research Technology Management., Volume. 38.

Kim, H.S. \& Shim, S. (2003), "Gender-based approach to the understanding of Leadership roles among retail managers", Human Resource Development Quarterly, Vol. 14 No. 3. http://dx.doi.org/10.1002/hrdq.1069

Likert, R.L. (1961). New Patterns of Management. McGraw-Hill, New York.

McGregor, D. (1960). The Human Side of Enterprise. New York: McGraw-Hill.

Pounder, J.S. (2001). "New Leadership and university organizational effectiveness: exploring the relationship", Leadership \& Organization Development Journal, Vol. $22 \quad$ No. 6. http://dx.doi.org/10.1108/EUM0000000005827

Rosenbach, W.E., \& Taylor, R.L. (1993), Contemporary issues in Leadership. Oxford Westview Press.

Sangomek, P., \& Ratanakomut., S. (2010). Criteria Factors of High Performance Organization (HPO) in the Air Force.

Senge, P . M. (1990). The Jifth discipline: The art and practice of the learning organization. New York, NY: Doubleday-Currency.

Stogdill, R.M. (1948). Personal factors associated with Leadership: A survey of thev literature. Journal of Personality.

Vroom, V.H., \& Yetton, P.N. (1973), Leadership and decision making. Pittburgh, PA University of Pittburgh Press. 